\title{
Biological Activities of Phosphocitrate: A Potential Meniscal Protective Agent
}

\author{
Yubo Sun, ${ }^{1}$ Andrea Roberts, ${ }^{1}$ David R. Mauerhan, ${ }^{1}$ Andrew R. Sun, \\ H. James Norton, ${ }^{2}$ and Edward N. Hanley Jr. ${ }^{1}$ \\ ${ }^{1}$ Department of Orthopedic Research Biology, Cannon Research, Carolinas Medical Center, P.O. Box 32861, Charlotte, NC 28232, USA \\ ${ }^{2}$ Dixon Advanced Analytics Group, Carolinas Medical Center, P.O. Box 32861, Charlotte, NC 28232, USA
}

Correspondence should be addressed to Yubo Sun; yubo.sun@carolinas.org

Received 18 March 2013; Revised 12 June 2013; Accepted 19 June 2013

Academic Editor: Toshihiro Nanki

Copyright (C) 2013 Yubo Sun et al. This is an open access article distributed under the Creative Commons Attribution License, which permits unrestricted use, distribution, and reproduction in any medium, provided the original work is properly cited.

Phosphocitrate (PC) inhibited meniscal calcification and the development of calcium crystal-associated osteoarthritis (OA) in Hartley guinea pigs. However, the mechanisms remain elusive. This study sought to examine the biological activities of PC in the absence of calcium crystals and test the hypothesis that PC is potentially a meniscal protective agent. We found that PC downregulated the expression of many genes classified in cell proliferation, ossification, prostaglandin metabolic process, and wound healing, including bloom syndrome RecQ helicase-like, cell division cycle 7 homolog, cell division cycle 25 homolog C, ankylosis progressive homolog, prostaglandin-endoperoxide synthases-1/cyclooxygenase-1, and plasminogen activator urokinase receptor. In contrast, PC stimulated the expression of many genes classified in fibroblast growth factor receptor signaling pathway, collagen fibril organization, and extracellular structure organization, including fibroblast growth factor 7, collagen type I, alpha 1, and collagen type XI, alpha 1. Consistent with its effect on the expression of genes classified in cell proliferation, collagen fibril organization, and ossification, PC inhibited the proliferation of OA meniscal cells and meniscal cell-mediated calcification while stimulating the production of collagens. These findings indicate that PC is potentially a meniscal-protective agent and a diseasemodifying drug for arthritis associated with severe meniscal degeneration.

\section{Introduction}

Osteoarthritis $(\mathrm{OA})$ is one of the most prevalent causes of disability in the aging population and has enormous economic and social consequences. However, existing nonsurgical treatment options only provide symptomatic relief but have no effect on the progression of the underlying disease or cartilage degeneration. The lack of progress in the development of disease-modifying drugs for OA therapy is largely due to our limited understanding of the pathogenesis of OA and our insufficient knowledge about the molecular targets for OA therapy.

Knee OA is not merely an articular cartilage disease, but a disease of the whole joint. An important local factor is the structural integrity of the menisci. In recent years, there has been a dramatic advance in our understanding of the integral role of the menisci for knee function and the consequences of meniscal abnormality on the development of OA. Studies have found that meniscal degeneration is a general feature of knee OA and contributes to joint space narrowing $[1,2]$. Meniscal lesions at baseline were more common in knees that developed OA than in the knees that did not develop OA during a 30-month follow-up period [3]. OA meniscal cells displayed a distinct gene expression profile different from normal meniscal cells [4]. These observations indicate that the meniscus is not a passive bystander in the disease process of knee OA $[5,6]$.

Basic calcium phosphate crystal and calcium pyrophosphate dihydrate crystal are the two most common articular calcium crystals. The presence of these crystals in OA articular cartilage and synovial fluid is well recognized. These crystals are also present in knee menisci of patients with endstage OA $[7,8]$. Studies found that these crystals stimulate cell mitogenesis, cell endocytotic activity, and the production 
of matrix metalloproteinases (MMPs) and inflammatory cytokines including interleukin-1 (IL-1) and prostaglandinendoperoxide synthase 2/cyclooxygenase-2 (PTGS2/Cox-2) [9-11]. However, there is still controversy as to whether these crystals are causative factors, factors that exacerbate OA, or simply bystanders.

Phosphocitrate (PC) is a naturally occurring compound originally identified in rat liver mitochondrial extracts and crab hepatopancreas [12]. Moro et al. and Romanello et al. suggested that PC could be formed in vivo through cytosolic phosphorylation of citric acid [13,14], which explains why it is nontoxic. Since its original identification, PC has been shown to be a powerful calcification inhibitor $[15,16]$. Tew et al. speculated that $\mathrm{PC}$ prevented $\mathrm{CaPO}_{4}$ precipitation in cells or cellular compartments containing high concentration of $\mathrm{Ca}^{2+}$ and $\mathrm{PO}_{4}$ [12]. PC prevented soft tissue calcification in vivo and did not produce any significant toxic side effect in rats when administered through intraperitoneal injections in doses up to $150 \mu \mathrm{mol} / \mathrm{kg} /$ day [17]. In cell cultures, PC inhibits calcium crystal-induced mitogenesis, expression of MMPs, and crystal-induced cell death [18-20]. In the Hartley guinea pig model of crystal-associated OA, PC inhibited meniscal calcification and reduced the severity of cartilage degeneration [21]. These observations provide support for the notion that crystals may play an important role in the development of OA and that calcification inhibitors are potentially disease-modifying drugs for crystal-associated OA therapy. However, two bisphosphonates, which are potent calcification inhibitors, failed to inhibit the development of OA in animal models of OA $[22,23]$, raising doubts as to whether calcification inhibitors are disease-modifying drugs for crystalassociated $\mathrm{OA}$ as well as the exact role of calcium crystals in the development of OA. In this study, we sought to examine the biological activities of PC in the absence of calcium crystals and test the hypothesis that PC has unique crystalindependent biological activities which may be responsible, at least in part, for its disease-modifying activity on OA and that $\mathrm{PC}$ is potentially a meniscal protective agent.

\section{Materials and Methods}

Dulbecco's Modified Eagle Medium, StemPro chondrogenesis differentiation medium, fetal bovine serum, Hank's balanced salt solution, and stock antibiotic and antimycotic mixture were products of Invitrogen (Carlsbad, CA, USA). $\mathrm{PC}$ was synthesized according to the procedure described [24]. All other chemicals are purchased from Sigma (St. Louis, MO, USA).

2.1. Cells. OA meniscal cells were prepared from menisci derived from patients with end-stage OA. Briefly, the medial menisci derived from patients with end-stage OA were processed to remove fatty and synovial tissues, minced into small pieces, and cultured in $100 \mathrm{~mm}$ plates at $37^{\circ} \mathrm{C}$ in medium containing $0.5 \%$ antibiotic/antimycotic solution and $10 \%$ serum. Every three or four days, the culture medium was changed. When the cells reached $70 \%$ confluence, they were passaged and maintained in medium containing $10 \%$ serum. Human foreskin fibroblasts were obtained from American Type Culture Collection (CRL-2429, Manassas, VA, USA). OA meniscal cells prepared from three OA patients were used in this study. OA menisci were collected with the approval of the authors' Institutional Review Board from OA patients undergoing knee joint replacement surgery. The need for informed consent was waived because those menisci were surgical waste, and no private patient information was collected.

2.2. Cell Culture and RNA Extraction. OA meniscal cells derived from three OA patients were harvested from cell culture plates and mixed and replated in four $100 \mathrm{~mm}$ cell culture plates at $90 \%$ confluence. On the second day, medium containing $1 \%$ serum was added. Twenty-four hours later, the medium in two plates was replaced with medium containing $1 \%$ serum and PC $(1 \mathrm{mM})$, and the medium in the other two plates was replaced with medium containing $1 \%$ serum without PC. Twenty-four hours later, total RNA was extracted from these cells using TRIzol reagent (Invitrogen, Carlsbad, CA, USA) and purified using Oligotex kit (Qiagen, Valencia, CA, USA). We repeated the experiment twice. Microarray was performed using these RNA samples (total six RNA samples).

2.3. Microarray. RNA samples extracted from three independent experiments were used for microarray analysis experiments. Briefly, double-stranded DNA was synthesized using SuperScript Double-Stranded cDNA Synthesis Kit (Invitrogen, San Diego, CA, USA). The DNA product was purified using GeneChip Sample Cleanup Module (Affymetrix, Santa Clara, CA, USA). cRNA was synthesized and biotin-labeled using BioArray high yield RNA transcript labeling kit (Enzo Life Sciences, Farmingdale, NY, USA). The cRNA product was purified using GeneChip Sample Cleanup Module and subsequently chemically fragmented. The fragmented and biotinylated cRNA was hybridized to HG-U133_Plus_2 GeneChip using Affymetrix Fluidics Station 400 (Affymetrix, Santa Clara, CA, USA). The fluorescent signals were quantified during two scans by Agilent Gene Array Scanner G2500A (Agilent Technologies, Palo Alto, CA, USA) and GeneChip operating Software (Affymetrix, Santa Clara, CA, USA). Genesifter (VizX Labs, Seattle, WA, USA) was used for the analysis of differential gene expression and gene ontology.

2.4. Real-Time RT-PCR. After microarray analyses, we mixed the RNA samples extracted from PC-treated OA meniscal cells (PC-treated RNA sample) and the RNA samples extracted from untreated OA meniscal cells (untreated RNA sample) and performed RT-PCR experiments. Briefly, cDNA was synthesized using TaqMan Reverse Transcription Reagents (Applied Biosystems, University Park, IL, USA) using the RNA samples described. Quantification of relative transcript levels for selected genes and the housekeeping gene glyceraldehyde 3-phosphate dehydrogenase (GAPDH) was performed using ABI7000 Real-Time PCR system (Applied Biosystems, University Park, IL, USA). TaqMan Gene Expression assay (Applied Biosystems, University Park, IL, USA) was used. CDNA samples were amplified with an initial Taq 
DNA polymerase activation step at $95^{\circ} \mathrm{C}$ for 10 minutes, followed by 40 cycles of denaturation at $95^{\circ} \mathrm{C}$ for 15 seconds and annealing at $60^{\circ} \mathrm{C}$ for one minute. Fold change was calculated, and the expression level of the genes to be examined was normalized to the expression level of GAPDH. RT-PCR experiment was performed in triplicates using the same RNA sample.

2.5. Cell Proliferation. OA meniscal cells $\left(2 \times 10^{4}\right)$ were plated in six well cluster plates and cultured in medium containing $10 \%$ serum in the presence of increasing amounts of PC (triplicates). Medium was changed every three days until the OA meniscal cells in the wells without $\mathrm{PC}$ reached $85 \%$ confluence. Cells were then harvested and cell numbers were determined using a hemocytometer. This experiment was repeated 3 times using OA meniscal cells derived from different patients. This proliferation assay was also performed using human primary foreskin fibroblasts.

2.6. Micromass Culture and Histology. OA meniscal cells were harvested from several $100 \mathrm{~mm}$ culture plates and suspended in medium containing $10 \%$ serum. For preparing a micromass, a droplet of the cell suspension containing $6 \times 10^{6}$ cells was placed in a well of a 24 -well plate. After placing all droplets, the plate was incubated for 4 hours at $37^{\circ} \mathrm{C}$ in a tissue culture incubator. These micromasses were then fed with StemPro chondrogenesis differentiation medium with PC $(1 \mathrm{mM})$ or without PC every three days throughout the experiment for 14 days. Each well was then rinsed twice with $500 \mu \mathrm{L}$ of Hank's balanced salt solution, and two drops of eosin were added to these wells. Five minutes later, eosin was aspirated off and the micromasses were transferred to a strip of filter paper which sat on the top of an ethanol-soaked sponge within a plastic cassette. The cassettes sat in a $10 \%$ formalin solution for one hour. These micromasses then underwent routine paraffin embedding. Sections were cut at $5 \mu \mathrm{m}$ thick and stained with picrosirius red for collagens, alcian blue for proteoglycans, and alizarin red for calcium deposits.

2.7. Cell-Mediated Calcification in Monolayer Culture. OA meniscal cells were plated in twenty-four well plates at $90 \%$ confluence. The next day, medium was replaced with StemPro chondrogenesis differentiation medium containing $1 \mathrm{mM}$ adenosine- $5^{\prime}$-triphosphate (ATP) in the absence or presence of PC $(1 \mathrm{mM})$. The cells were cultured for 14 days and fed with StemPro chondrogenesis differentiation medium containing ATP every three or four days throughout the experiment. At the end of the experimental period, media were removed. Calcification was examined using alizarin red.

2.8. Statistical Analysis. For cell proliferation, data are expressed as the mean $\pm \mathrm{SD}$, and the difference between two groups was analyzed using Student's $t$-test. For realtime RT-PCR, experiment was repeated in triplicates. The difference between two experimental groups was analyzed using Student's $t$ test. In all cases, $P$ values less than 0.01 were considered significant. Statistical analysis was performed using the SAS software, version 9.3.

\section{Results}

3.1. Effect of PC on Gene Expression. We performed three microarray experiments (PC-treated RNA sample I and untreated RNA sample I; PC-treated RNA sample II and untreated RNA sample II; PC-treated RNA sample III and untreated RNA sample III) as described. The results of the three microarray experiments were quite similar. The results of the first microarray experiment showed that of the more than 50,000 transcripts, 2445 transcripts displayed significant differential expression (more than 1.6-fold changes) in the PC-treated OA meniscal cells compared with the untreated OA meniscal cells. A total of 1795 transcripts displayed decreased expression and 650 transcripts displayed increased expression. The genes that fell into specific biological processes previously implicated in $\mathrm{OA}$, or suspected to have a role in $\mathrm{OA}$ are listed in Tables 1 and 2.

As shown in Table 1, the expression of numerous genes classified in cell proliferation was downregulated by PC. Of the 62 differentially expressed genes (more than 2-fold changes) classified in cell proliferation, the expression of 52 genes, including bloom syndrome recq helicase-like (BLM; -7.41-fold change), lymphoid-specific helicase (Hells; -4.46fold change), cell division cycle 7 homolog (CDC7; -4.11fold change), CDC 25 homolog C (CDC25C; -2.36-fold change), and cyclin E2 (CCNE2, -3.51-fold change), was downregulated by PC. This specific downregulatory effect of $\mathrm{PC}$ on the expression of genes classified in cell proliferation suggests that PC may inhibit the proliferation of OA meniscal cells.

The expressions of many genes classified in ossification and bone morphogenetic protein (BMP) signaling pathway were also downregulated by PC (Table 1). Of the 22 differentially expressed genes classified in ossification, the expression of 13 genes, including collagen, type XIII, alpha 1 (COL13A1; -3.39-fold change), special AT-rich sequence-binding protein (SATB2; -3.13), mothers against DPP homolog 1/SMAD family member 1 (SMAD1; -2.19), ectonucleotide pyrophosphatase/phosphodiesterase 1 (ENPP1; -2.02-fold change), and ankylosis progressive homolog (ANKH; -1.60-fold change), was downregulated by PC. The expression of 9 genes, including insulin-like growth factor-binding protein 5 (IGFBP5; 1.78-fold change) and matrix Gla protein (MGP; 1.61-fold change), was upregulated by PC. Of the 8 differentially expressed genes classified in BMP signaling pathway, the expression of all 8 genes, including BMP receptor, type IB (BMPR1B; -1.93-fold change), was downregulated by PC.

In addition, the expression of several genes classified in prostaglandin metabolic process and respond to wounding was downregulated by PC (Table 1). Of the 5 differentially expressed genes classified in prostaglandin metabolic process, the expression of 3 genes, including prostaglandin-endoperoxide synthase 1/cyclooxygenase-1 (PTGS1/Cox-1; -2.13-fold change), phospholipase A2, group IVA (PLA2G4A; -1.61-fold change), was downregulated by PC. Of the 9 differentially expressed genes classified in respond to wounding, the expression of 7 genes, including thrombomodulin (THBD; -4.24-fold change), plasminogen activator, tissue (PLAT, -3.12 -fold change) and plasminogen 
TABLE 1: Differentially expressed genes in PC-treated via untreated OA meniscal cells.

\begin{tabular}{|c|c|c|c|c|}
\hline $\begin{array}{l}\text { Biological } \\
\text { process }\end{array}$ & $\begin{array}{l}\text { Gene } \\
\text { name }\end{array}$ & Gene ID & $\begin{array}{l}\text { Differential } \\
\text { expression }\end{array}$ & Description \\
\hline \multirow{50}{*}{ Cell proliferation } & BLM & NM_000057 & -7.41 & Bloom syndrome, RecQ helicase-like \\
\hline & NDP & NM_000266 & -4.68 & Norrie disease (pseudoglioma) \\
\hline & HELLS & AF155827 & -4.46 & Helicase, lymphoid specific \\
\hline & E2F7 & AI341146 & -4.12 & E2F transcription factor 7 \\
\hline & $\mathrm{CDC7}$ & NM_003503 & -4.11 & Cell division cycle 7 homolog (S. cerevisiae) \\
\hline & CDCA7 & AY029179 & -2.71 & Cell division cycle-associated 7 \\
\hline & CDC25C & NM_001790 & -2.36 & Cell division cycle 25 homolog C (S. pombe) \\
\hline & BRCA1 & AF005068 & -3.60 & Breast cancer 1 , early onset \\
\hline & BRCA2 & X95152 & -3.30 & Breast cancer 2, early onset \\
\hline & PRKRA & AA279462 & -3.34 & PKinase, interferon-indu double-stranded RNA-dependent activator \\
\hline & HHIP & AK098525 & -3.28 & Hedgehog interacting protein \\
\hline & CHEK1 & AA224205 & -3.11 & CHK1 checkpoint homolog (S. pombe) \\
\hline & PTPRK & AU145587 & -3.08 & Protein tyrosine phosphatase, receptor type, $K$ \\
\hline & GINS1 & NM_021067 & -3.07 & GINS complex subunit 1 (Psf1 homolog) \\
\hline & TCF19 & BC002493 & -2.93 & Transcription factor 19 \\
\hline & MKI67 & AU147044 & -2.92 & Antigen identified by monoclonal antibody Ki- 67 \\
\hline & PDS5B & AK026889 & -2.88 & PDS5, regulator of cohesion maintenance, homolog B \\
\hline & UHRF1 & AK025578 & -2.77 & Ubiquitin-like with PHD and ring finger domains 1 \\
\hline & AURKB & АB011446 & -2.64 & Aurora kinase B \\
\hline & MKI67 & AU132185 & -2.64 & Antigen identified by monoclonal antibody Ki-67 \\
\hline & FIGNL1 & NM_022116 & -2.62 & Fidgetin-like 1 \\
\hline & KIF15 & NM_020242 & -2.60 & Kinesin family member 15 \\
\hline & LRP6 & NM_002336 & -2.55 & Low-density lipoprotein receptor-related protein 6 \\
\hline & ANXA1 & AU155094 & -2.47 & Annexin A1 \\
\hline & DDX11 & U33833 & -2.47 & DEAD/H (Asp-Glu-Ala-Asp/His) box polypeptide 11 \\
\hline & FANCA & AW083279 & -2.46 & Fanconi anemia, complementation group A \\
\hline & SPRY2 & NM_005842 & -2.43 & Sprouty homolog 2 (Drosophila) \\
\hline & RECQL4 & NM_004260 & -2.43 & RecQ protein-like 4 \\
\hline & NTN1 & BF591483 & -2.42 & Netrin 1 \\
\hline & ADRB2 & NM_000024 & -2.41 & Adrenergic, beta-2, receptor, surface \\
\hline & CUL4A & AU155661 & -2.40 & Cullin $4 \mathrm{~A}$ \\
\hline & DLC1 & NM_024767 & -2.39 & Deleted in liver cancer 1 \\
\hline & STIL & NM_003035 & -2.39 & SCL/TAL1 interrupting locus \\
\hline & CHEK1 & NM_001274 & -2.37 & CHK1 checkpoint homolog (S. pombe) \\
\hline & TIMELESS & NM_003920 & -2.37 & Timeless homolog (Drosophila) \\
\hline & SMAD4 & AL832789 & -2.23 & SMAD family member 4 \\
\hline & SMAD1 & NM_015583 & -2.19 & SMAD family member 1 \\
\hline & PCNA & NM_002592 & -2.18 & Proliferating cell nuclear antigen \\
\hline & PRKCD & NM_006254 & -2.17 & Protein kinase $\mathrm{C}$, delta \\
\hline & RBBP4 & AI972451 & -2.16 & Retinoblastoma binding protein 4 \\
\hline & PTGS1 & NM_000962 & -2.13 & Prostaglandin-endoperoxide synthase 1 \\
\hline & ASPM & NM_018123 & -2.13 & Abnormal spindle (asp) homolog, microcephaly associated \\
\hline & GLMN & AA814383 & -2.11 & Glomulin, FKBP associated protein \\
\hline & NASP & NM_002482 & -2.11 & Nuclear autoantigenic sperm protein (histone binding) \\
\hline & CCNA2 & NM_001237 & -2.09 & Cyclin A2 \\
\hline & TBX2 & AW173045 & -2.08 & T-box 2 \\
\hline & KIF2C & U63743 & -2.08 & Kinesin family member $2 \mathrm{C}$ \\
\hline & PDCD1LG2 & AF329193 & -2.06 & Programmed cell death 1 ligand 2 \\
\hline & BUB1B & NM_001211 & -2.05 & Budding uninhibited by benzimidazoles 1 homolog beta (yeast) \\
\hline & POLA1 & NM_016937 & -2.04 & Polymerase (DNA directed), alpha 1, catalytic subunit \\
\hline
\end{tabular}


TABle 1: Continued.

\begin{tabular}{|c|c|c|c|c|}
\hline $\begin{array}{l}\text { Biological } \\
\text { process }\end{array}$ & $\begin{array}{l}\text { Gene } \\
\text { name }\end{array}$ & Gene ID & $\begin{array}{l}\text { Differential } \\
\text { expression* }\end{array}$ & Description \\
\hline \multirow{12}{*}{ Cell proliferation } & TACC3 & NM_006342 & -2.02 & Transforming, acidic coiled-coil containing protein 3 \\
\hline & CDK2 & M68520 & -2.01 & Cyclin-dependent kinase 2 \\
\hline & DLX5 & NM_005221 & 2.99 & Distal-less homeobox 5 \\
\hline & VCAM1 & NM_001078 & 2.88 & Vascular cell adhesion molecule 1 \\
\hline & ADORA1 & NM_000674 & 2.48 & Adenosine $\mathrm{A} 1$ receptor \\
\hline & TNFRSF9 & NM_001561 & 2.38 & Tumor necrosis factor receptor superfamily, member 9 \\
\hline & FGF9 & NM_002010 & 2.38 & Fibroblast growth factor 9 (glia-activating factor) \\
\hline & FABP3 & NM_004102 & 2.24 & Fatty acid binding protein 3 , muscle, and heart \\
\hline & FGFR2 & M87771 & 2.20 & Fibroblast growth factor receptor 2 \\
\hline & BAMBI & NM_012342 & 2.13 & BMP and activin membrane-bound inhibitor homolog \\
\hline & CD24 & L33930 & 2.09 & CD24 molecule \\
\hline & HSF1 & AI393937 & 2.07 & Heat shock transcription factor 1 \\
\hline \multirow{22}{*}{ Ossification } & COL13A1 & M33653 & -3.39 & Collagen, type XIII, alpha 1 \\
\hline & SATB2 & AK025127 & -3.13 & SATB homeobox 2 \\
\hline & ADRB2 & NM_000024 & -2.41 & Adrenergic, beta-2, receptor, surface \\
\hline & SMAD1 & NM_015583 & -2.19 & SMAD family member 1 \\
\hline & ENPP1 & BF591996 & -2.02 & Ectonucleotide pyrophosphatase/phosphodiesterase 1 \\
\hline & BMPR1B & AA935461 & -1.93 & Bone morphogenetic protein receptor, type IB \\
\hline & NAB1 & AF045452 & -1.87 & NGFI-A-binding protein 1 (EGR1-binding protein 1) \\
\hline & GNAS & AA810695 & -1.86 & GNAS complex locus \\
\hline & FGF18 & BC006245 & -1.73 & Fibroblast growth factor 18 \\
\hline & TNFRSF11A & AW026379 & -1.67 & Tumor necrosis factor receptor superfamily, member 11a \\
\hline & EGFR & K03193 & -1.61 & Epidermal growth factor receptor \\
\hline & PLA2G4A & M68874 & -1.61 & Phospholipase A2, group IVA (cytosolic, calcium dependent) \\
\hline & ANKH & T99215 & -1.60 & Ankylosis, progressive homolog (mouse) \\
\hline & DLX5 & NM_005221 & 2.99 & Distal-less homeobox 5 \\
\hline & FGF9 & NM_002010 & 2.38 & Fibroblast growth factor 9 (glia-activating factor) \\
\hline & IGFBP5 & R73554 & 1.78 & Insulin-like growth factor-binding protein 5 \\
\hline & GABBR1 & N45228 & 1.72 & Gamma-aminobutyric acid (GABA) B receptor, 1 \\
\hline & MMP14 & NM_004995 & 1.72 & Matrix metallopeptidase 14 (membrane inserted) \\
\hline & TUFT1 & NM_020127 & 1.66 & Tuftelin 1 \\
\hline & COL1A1 & AI743621 & 1.62 & Collagen, type I, alpha 1 \\
\hline & MGP & NM_000900 & 1.61 & Matrix Gla protein \\
\hline & SMAD3 & BF971416 & 1.60 & SMAD family member 3 \\
\hline \multirow{8}{*}{$\begin{array}{l}\text { BMP signaling } \\
\text { pathway }\end{array}$} & UBE2D3 & AI239832 & -2.44 & Ubiquitin-conjugating enzyme E2D 3 (UBC4/5 homolog, yeast) \\
\hline & ZFYVE16 & ВC032227 & -2.43 & Zinc finger, FYVE domain containing 16 \\
\hline & SMAD4 & AL832789 & -2.23 & SMAD family member 4 \\
\hline & SMAD1 & NM_015583 & -2.19 & SMAD family member 1 \\
\hline & BMPR1B & AA935461 & -1.93 & Bone morphogenetic protein receptor, type IB \\
\hline & HIPK2 & AW300045 & -1.91 & Homeodomain interacting protein kinase 2 \\
\hline & MSX1 & AI421295 & -1.84 & Msh homeobox 1 \\
\hline & GREM2 & NM_022469 & -1.73 & Gremlin 2, cysteine knot superfamily, homolog (Xenopus laevis) \\
\hline \multirow{6}{*}{$\begin{array}{l}\text { Prostaglandin } \\
\text { metabolic process }\end{array}$} & PTGS1 & NM_000962 & -2.13 & Prostaglandin-endoperoxide synthase 1 \\
\hline & AKR1C2 & BF508244 & -1.91 & Aldo-keto reductase family 1 , member $\mathrm{C} 2$ \\
\hline & PLA2G4A & M68874 & -1.61 & Phospholipase A2, group IVA (cytosolic, calcium dependent) \\
\hline & PTGS2 & NM_000963 & -1.33 & Prostaglandin-endoperoxide synthase 2 \\
\hline & PTGIS & D38145 & 1.79 & Prostaglandin I2 (prostacyclin) synthase \\
\hline & PDPN & AW590196 & 1.61 & Podoplanin \\
\hline
\end{tabular}


TABle 1: Continued.

\begin{tabular}{lcccl}
\hline $\begin{array}{l}\text { Biological } \\
\text { process }\end{array}$ & $\begin{array}{c}\text { Gene } \\
\text { name }\end{array}$ & Gene ID & $\begin{array}{c}\text { Differential } \\
\text { expression }\end{array}$ & Description \\
\hline THBD & AW119113 & -4.24 & Thrombomodulin \\
& PLAT & NM_000930 & -3.12 & Plasminogen activator, tissue \\
Response to & TFPI & J03225 & -2.66 & Tissue factor pathway inhibitor \\
wounding & TFPI2 & AL574096 & -2.38 & Tissue factor pathway inhibitor 2 \\
& SDC1 & NM_002997 & -2.38 & Syndecan 1 \\
& SMAD1 & NM_015583 & -2.19 & SMAD family member 1 \\
& PLAUR & AY029180 & -1.94 & Plasminogen activator, urokinase receptor \\
& TMPRSS6 & AI912086 & 1.96 & Transmembrane protease, serine 6 \\
& JUB & NM_032876 & 1.92 & Jub, ajuba homolog (Xenopus laevis) \\
\hline
\end{tabular}

${ }^{*}$ Negative number indicates decreased expression and positive number indicates elevated expression (fold change) in PC-treated OA meniscal cells compared with untreated OA meniscal cells.

TABLE 2: Differentially expressed genes in PC-treated via untreated OA meniscal cells.

\begin{tabular}{|c|c|c|c|c|}
\hline $\begin{array}{l}\text { Biological } \\
\text { process }\end{array}$ & $\begin{array}{l}\text { Gene } \\
\text { name }\end{array}$ & Gene ID & $\begin{array}{l}\text { Differential } \\
\text { expression* }\end{array}$ & Description \\
\hline \multirow{7}{*}{$\begin{array}{l}\text { FGF receptor } \\
\text { signaling pathway }\end{array}$} & FGF9 & NM_002010 & 2.38 & Fibroblast growth factor 9 (glia-activating factor) \\
\hline & FGFR2 & M87771 & 2.20 & Fibroblast growth factor receptor 2 \\
\hline & FGF7 & NM_002009 & 1.83 & Fibroblast growth factor 7 (keratinocyte growth factor) \\
\hline & NDST1 & AL526632 & 1.71 & N-deacetylase/N-sulfotransferase (heparan glucosaminyl) 1 \\
\hline & THBS1 & AI812030 & 1.68 & Thrombospondin 1 \\
\hline & HHIP & AK098525 & -3.28 & Hedgehog interacting protein \\
\hline & FGF18 & BC006245 & -1.73 & Fibroblast growth factor 18 \\
\hline \multirow{8}{*}{$\begin{array}{l}\text { Collagen fibril } \\
\text { organization }\end{array}$} & COL14A1 & M64108 & 2.06 & Collagen, type XIV, alpha 1 \\
\hline & COL11A1 & J04177 & 1.82 & Collagen, type XI, alpha 1 \\
\hline & COL1A1 & AI743621 & 1.62 & Collagen, type I, alpha 1 \\
\hline & SERPINH1 & NM_004353 & 1.66 & Serpin peptidase inhibitor, clade $\mathrm{H}$, member 1 \\
\hline & DPT & AI146848 & 1.65 & Dermatopontin \\
\hline & TRAM2 & BC028121 & 1.60 & Translocation-associated membrane protein 2 \\
\hline & COL5A1 & AI983428 & 1.52 & Collagen, type V, alpha 1 \\
\hline & COL5A2 & NM_000393 & 1.44 & Collagen, type V, alpha 2 \\
\hline \multirow{15}{*}{$\begin{array}{l}\text { Extracellular } \\
\text { structure } \\
\text { organization }\end{array}$} & CACNA1A & NM_023035 & 2.55 & Calcium channel, voltage dependent, $\mathrm{P} / \mathrm{Q}$ type, alpha 1A subunit \\
\hline & COL14A1 & M64108 & 2.06 & Collagen, type XIV, alpha 1 \\
\hline & ECM2 & NM_001393 & 2.04 & Extracellular matrix protein 2 , female organ, and adipocyte specific \\
\hline & MYO6 & AA877789 & 1.98 & Myosin VI \\
\hline & TMPRSS6 & AI912086 & 1.96 & Transmembrane protease, serine 6 \\
\hline & COL11A1 & J04177 & 1.82 & Collagen, type XI, alpha 1 \\
\hline & CRISPLD2 & AL136861 & 1.74 & Cysteine-rich secretory protein LCCL domain containing 2 \\
\hline & HSD17B12 & BC012536 & 1.68 & Hydroxysteroid (17-beta) dehydrogenase 12 \\
\hline & SERPINH1 & NM_004353 & 1.66 & Serpin peptidase inhibitor, clade $\mathrm{H}$, member 1 \\
\hline & DCN & AI336924 & 1.65 & Decorin \\
\hline & DPT & AI146848 & 1.65 & Dermatopontin \\
\hline & COL1A1 & AI743621 & 1.62 & Collagen, type I, alpha 1 \\
\hline & APLP1 & U48437 & 1.61 & Amyloid beta (A4) precursor-like protein 1 \\
\hline & NFASC & AI821777 & -1.99 & Neurofascin homolog (chicken) \\
\hline & MMP9 & NM_004994 & -1.91 & Matrix metallopeptidase 9 \\
\hline
\end{tabular}


TABLe 2: Continued.

\begin{tabular}{|c|c|c|c|c|}
\hline $\begin{array}{l}\text { Biological } \\
\text { process }\end{array}$ & $\begin{array}{l}\text { Gene } \\
\text { name }\end{array}$ & Gene ID & $\begin{array}{l}\text { Differential } \\
\text { expression* }\end{array}$ & Description \\
\hline \multirow{26}{*}{$\begin{array}{l}\text { Inflammatory } \\
\text { response }\end{array}$} & ADORA1 & NM_000674 & 2.48 & Adenosine A1 receptor \\
\hline & CD24 & L33930 & 2.09 & CD24 molecule \\
\hline & BCL6 & S67779 & 1.98 & B-cell CLL/lymphoma 6 \\
\hline & NGF & NM_002506 & 1.84 & Nerve growth factor (beta polypeptide) \\
\hline & CFD & NM_001928 & 1.82 & Complement factor D (adipsin) \\
\hline & ITGB2 & NM_000211 & 1.80 & Integrin, beta 2 \\
\hline & CFI & ВС020718 & 1.74 & Complement factor I \\
\hline & NDST1 & AL526632 & 1.71 & $\mathrm{~N}$-deacetylase/N-sulfotransferase (heparan glucosaminyl) 1 \\
\hline & IL17C & AF152099 & 1.70 & Interleukin $17 \mathrm{C}$ \\
\hline & THBS1 & AI812030 & 1.68 & Thrombospondin 1 \\
\hline & SERPINA3 & NM_001085 & 1.67 & Serpin peptidase inhibitor, clade A, member 3 \\
\hline & AGTR1 & NM_004835 & 1.65 & Angiotensin II receptor, type 1 \\
\hline & TFRC & N76327 & 1.64 & Transferrin receptor (p90, CD71) \\
\hline & PDPN & AW590196 & 1.61 & Podoplanin \\
\hline & MASP1 & AI274095 & 1.61 & Mannan-binding lectin serine peptidase 1 \\
\hline & NFKBIZ & BE646573 & -2.58 & $\mathrm{NFKb}$ inhibitor, zeta \\
\hline & ANXA1 & AU155094 & -2.47 & Annexin A1 \\
\hline & ADRB2 & NM_000024 & -2.41 & Adrenergic, beta-2, receptor, surface \\
\hline & SMAD1 & NM_015583 & -2.19 & SMAD family member 1 \\
\hline & CXCL6 & NM_002993 & -2.19 & Chemokine (C-X-C motif) ligand 6 \\
\hline & $\mathrm{C} 2$ & NM_000063 & -2.18 & Complement component 2 \\
\hline & BMPR1B & AA935461 & -1.93 & Bone morphogenetic protein receptor, type IB \\
\hline & TNFRSF1B & NM_001066 & -1.74 & Tumor necrosis factor receptor superfamily, member $1 \mathrm{~B}$ \\
\hline & EDNRA & NM_001957 & -1.67 & Endothelin receptor type A \\
\hline & PLA2G4A & M68874 & -1.61 & Phospholipase A2, group IVA (cytosolic, calcium dependent) \\
\hline & GPR68 & AI805006 & -1.60 & G protein-coupled receptor 68 \\
\hline
\end{tabular}

${ }^{*}$ Negative number indicates decreased expression and positive number indicates elevated expression (fold change) in PC-treated OA meniscal cells compared with untreated OA meniscal cells.

activator, urokinase receptor (PLAUR; -1.94 -fold change), was downregulated by PC.

Many genes that were upregulated by PC fell into the biological processes of fibroblast growth factor (FGF) receptor signaling pathway, collagen fibril organization, and extracellular structure organization (Table 2). Of the 7 differentially expressed genes classified in FGF receptor signaling pathway, the expression of 5 genes, including FGF7 (1.83fold change), FGF9 (2.38-fold change), and FGF receptor 2 (FGFR2; 2.20 fold change), was upregulated by PC. Of the 6 differentially expressed genes classified in collagen fibril organization, the expression of all 6 genes, including collagen type I, alpha 1 (COL1A1; 1.62-fold change), collagen type XI, alpha 1 (COL11A1; 1.82 -fold change), and collagen type XIV, alpha 1 (COL14A1; 2.06-fold change), was upregulated by PC. Further examination of the microarray data indicated that the expression of collagen type $\mathrm{V}$, alpha 1 (COL5A1; 1.52 fold change) and collagen type V, alpha 2 (COL5A2; 1.44-fold change) was also upregulated by PC although the changes were less than 1.6-fold (Table 2). Of the 15 genes differentially expressed genes classified in extracellular structure organization, the expression of 13-genes, including extracellular matrix protein 2 (ECM2; 2.04-fold change), was upregulated by PC. Only 2 genes, including MMP9 (-1.91-fold change), were downregulated by PC (Table 2).
Finally, of the 26 genes classified in inflammatory response, the expression of 15 genes, including adenosine A1 receptor (ADORA1; 2.48-fold change), CD24 molecule (CD24; 2.09-fold change), and B-cell CLL/lymphoma 6 (BCL6; 1.98-fold change), was upregulated by PC. The expression of 11 genes, including NF-kappaB inhibitor zeta (NFKBIZ; -2.58 -fold change), adrenergic, beta-2, receptor (ADRB2; -2.41-fold change), and chemokine (C-X-C motif) ligand 6 (CXCL6; -2.19-fold change), was downregulated by PC (Table 2).

3.2. Real-Time RT-PCR. Real-time RT-PCR was used to confirm expression of selected genes. The results are listed in Table 3. As shown, the differential expression of the genes examined was confirmed by real-time RT-PCR $(P<0.01)$.

3.3. PC Inhibited Proliferation of OA Meniscal Cells. The specific downregulatory effect of PC on the expression of genes classified in cell proliferation suggests that PC may inhibit the proliferation of OA meniscal cells. To test this, we cultured OA meniscal cells in the absence and presence of PC for 9 days and then determined the cell number using a hemocytometer. Indeed, we found that PC inhibited the proliferation of OA meniscal cells (Figure 1(a), right bar 
TABLE 3: Differential expression confirmed by real-time RT-PCR.

\begin{tabular}{lcccc}
\hline Gene name & Gene ID & Differential expression microarray & Differential expression ${ }^{*}$ RT-PCR & Differential expression $^{* *}$ RT-PCR \\
\hline BLM & NM_000057 & -7.41 & -5.54 & -6.54 \\
HELLS & AF155827 & -4.46 & -4.17 & -4.87 \\
CDC25C & NM_001790 & -2.36 & -2.18 & -2.92 \\
CDC6 & NM_001254 & -2.00 & -2.20 & -3.41 \\
CCNE2 & NM_004702 & -3.51 & -2.94 & -3.46 \\
CCNA2 & A1346350 & -2.00 & -2.34 & -1.78 \\
ANKH & T99215 & -1.60 & -1.42 & -1.86 \\
PTGS1 & NM_000962 & -2.13 & -2.43 & -2.98 \\
THBD & AW119113 & -4.24 & -4.51 & -3.79 \\
FGF7 & NM_002009 & 1.83 & 1.96 & 2.32 \\
FGF9 & NM_002010 & 2.38 & 2.47 & 2.70 \\
COL11A1 & J04177 & 1.82 & 1.96 & 2.01 \\
ECM2 & NM_001393 & 2.04 & 2.71 & 2.15 \\
IGFBP5 & R73554 & 1.78 & 1.95 & 2.34 \\
CD24 & L33930 & 2.09 & 2.32 & 3.10 \\
\hline
\end{tabular}

${ }^{*}$ RT-PCR was performed using the RNA samples that were used for microarray analyses. ${ }^{* *}$ RT-PCR was performed using RNA samples from another experiment.

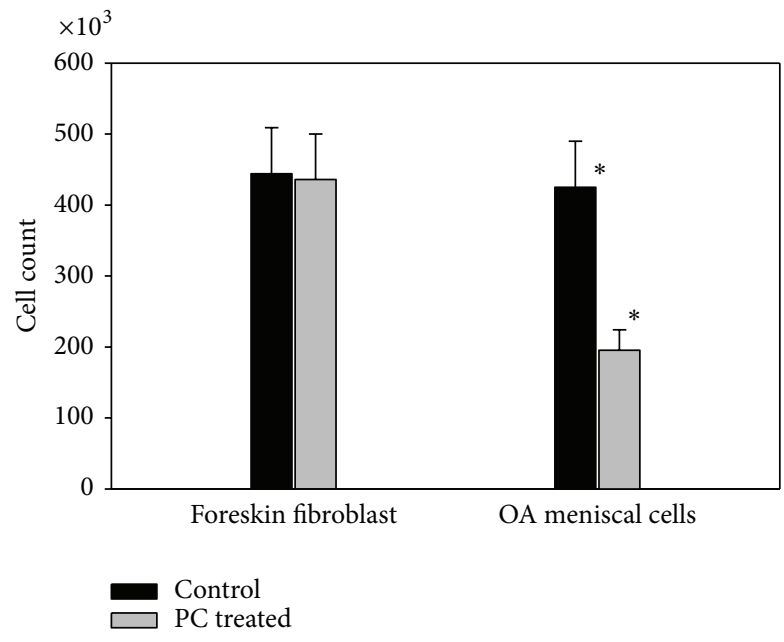

(a)

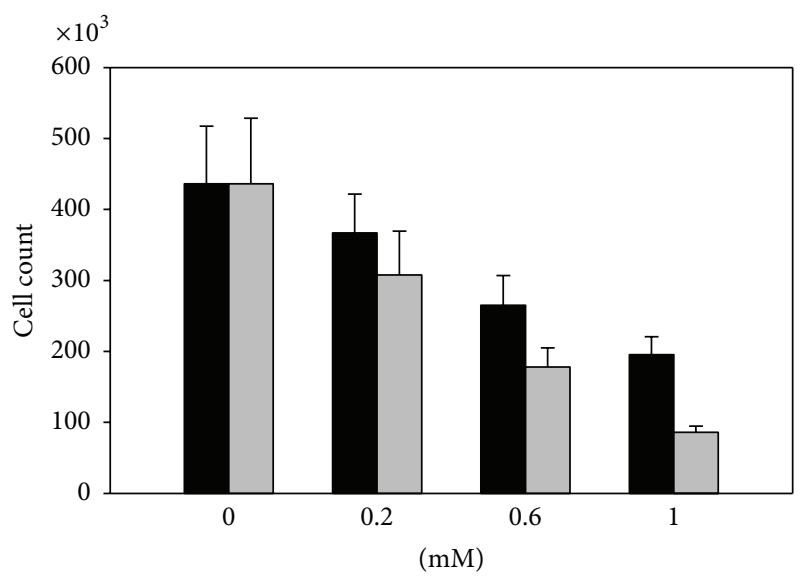

PC treated EHDP treated

(b)

FIgURE 1: PC inhibited the proliferation of OA meniscal cells. OA meniscal cells and human foreskin fibroblast were plated in six-well cluster plates and cultured in the presence or absence of PC. (a) There were about 55\% fewer OA meniscal cells in the PC-treated (1 mM PC) wells than that in the untreated wells (the right bar group; $P=0.0032$ ). In contract, PC had no effect on the proliferation of human foreskin fibroblast (the left group bars). (b) PC and EHDP inhibited the proliferation of OA meniscal cells in a dose-dependent manner.

group). There were $55 \%$ fewer OA meniscal cells in the PC-treated wells than that in the untreated wells $(P<$ $0.01)$. In contrast, $P C$ had no effect on the proliferation of human foreskin fibroblasts (Figure 1(a), left bar group). For comparison, we also examined the effect of disodium salt of ethane-1-hydroxy-1, 1-bisphosphonic acid (EHDP), which is a bisphosphonate, together with $\mathrm{PC}$ on the proliferation of OA meniscal cells. As shown in Figure 1(b), both PC and EHDP inhibited the proliferation of OA meniscal cells in a dose-dependent manner. In addition, the morphology of PCtreated OA meniscal cells and untreated OA meniscal cells was similar (not shown), indicating that the reduction in cell number was not due to cellular toxicity of PC.
3.4. PC Stimulated Production of Collagens. The upregulatory effect of PC on the expression of genes classified in collagen fibril organization, including COL1A1 (1.62-fold change), COL11A1 (1.82-fold change), COL14A1 (2.06-fold change), COL5A1 (1.52-fold change), and COL5A2 (1.44-fold change), suggests that PC may stimulate the production of collagens by the OA meniscal cells. To examine this, we prepared micromasses of OA meniscal cells (triplicates) and examined the production of collagens using picrosirius red staining. The results confirmed that PC stimulated the production of collagens by OA meniscal cells. Representative images of picrosirius red staining are shown in Figure 2. As shown, the picrosirius red staining in the PC-treated micromasses 

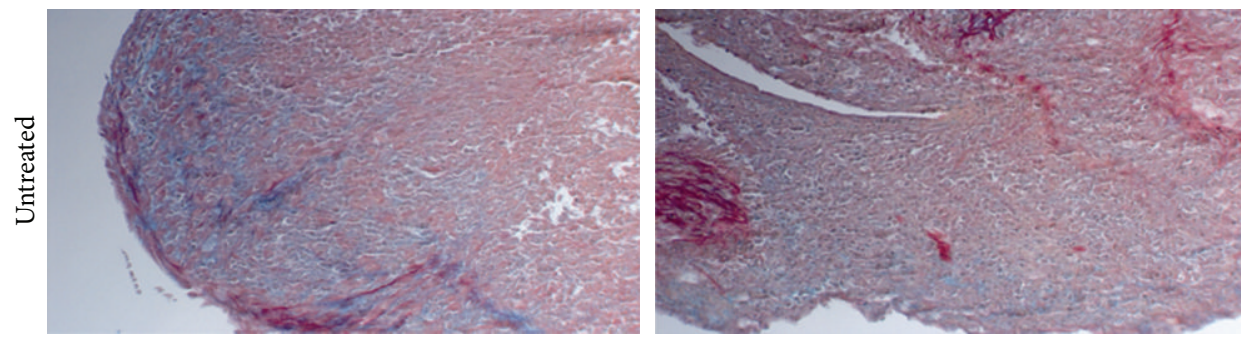

(a)
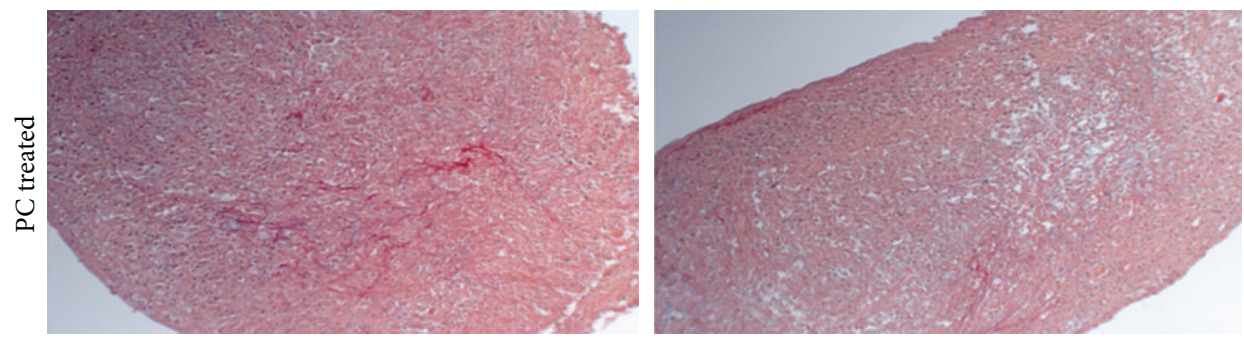

(b)

FIGURE 2: PC stimulated the production of collagens. Micromasses of OA meniscal cells were cultured in the absence of PC ((a); magnification 10x) or the presence of $1 \mathrm{mM}$ PC ((b); magnification 10x) for 14 days. These micromasses were then processed and stained with picrosirius red. Note the much stronger picrosirius red staining in the PC-treated micromass than that in the untreated micromass.

(Figure 2(b)) was stronger than that in the untreated micromasses (Figure 2(a)). These micromasses were also stained with alcian blue. Results indicated that PC had no detectable effect of the production of proteoglycans (not shown).

\subsection{PC Inhibited Meniscal Cell-Mediated Calcification. These} micromasses were also stained with alizarin red for calcium deposits. Representative images of alizarin red staining are shown in Figure 3. As shown, many calcium deposits were detected in the micromasses of OA meniscal cells cultured in the absence of PC (Figure 3(a)), but no calcium deposits were detected in the micromasses cultured in the presence of PC (Figure $3(\mathrm{~b}))$. PC treatment $(1 \mathrm{mM})$ abolished OA meniscal cell-mediated calcium deposition in micromass culture completely.

The inhibitory effect of PC on OA meniscal cell-mediated calcification was also examined using monolayer culture. As shown in Figure 4, calcium deposits were detected in the monolayer culture of OA meniscal cells (Figure 4(a), but no calcium deposits were detected in the monolayer culture of OA meniscal cells cultured in the presence of PC (Figure 4(b)).

\section{Discussion}

Increased number and size of cell clusters are the hallmark histological feature of OA articular cartilage [25, 26]. Cell clusters are activated cells and represent an important source of pathological mediator. The number of proliferating chondrocytes increases during OA progression [26, 27]. Cell clusters are also detected in OA menisci [28]. These observations indicate that abnormal cell activation and proliferation may play a role in the development and/or progression of OA. In this study, we demonstrated that PC downregulated the expression of numerous genes associated with cell proliferation. Consistent with this regulatory effect, PC inhibited the proliferation of OA meniscal cells. Although the exact implication of this effect on the development of $\mathrm{OA}$ is unclear at present, these findings suggest that $\mathrm{PC}$ may inhibit the activation of OA meniscal cells or inhibit the formation of cell clusters.

Studies consistently reported apoptotic cells in cell clusters $[29,30]$. One of the mechanisms of apoptosis is abnormal hypertrophic differentiation of chondrocytes and subsequent pathological calcification. There is abundant evidence indicating the expression of hypertrophic makers, including collagen X, osteocalcin, and MMP13, within the cell clusters [31-33]. In addition, staining of OA cartilage sections showed colocalization of calcium deposits and clusters containing apoptotic cells adjacent to the calcium deposits [34]. Mineralization of extracellular matrix surrounding cell clusters was also detected in OA menisci [28]. These observations indicate that abnormal cell activation, terminal differentiation, pathological calcification, and apoptosis may be mutually linked disease processes in OA. In this study, we demonstrated that PC inhibited the expression of numerous genes associated with cell proliferation, differentiation, and pathological calcification, including CDC7 (-4.11-fold change), CDC25C (-2.36-fold change), COL13A1 (-3.39fold change), SATB2 (-3.13-fold-change), SMAD1 (-2.19-fold change), ENPP1 (-2.02-fold change), and ANKH (-1.60-fold change). Consistent with this regulatory activity, $\mathrm{PC}$ inhibited the proliferation of OA meniscal cells and abolished meniscal cells-mediated calcification. These findings suggest that PC may exert its disease-modifying activity in part by targeting the genes associated with cell proliferation, differentiation, and pathological calcification. 

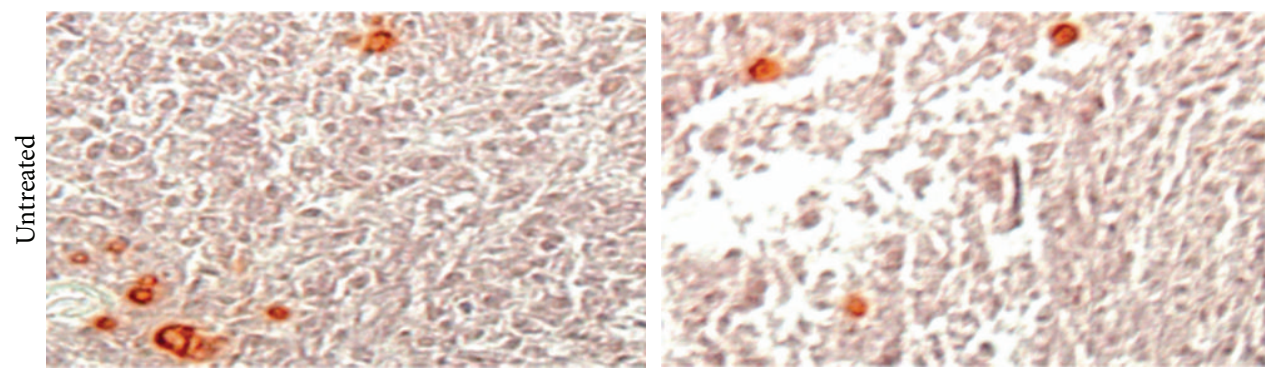

(a)
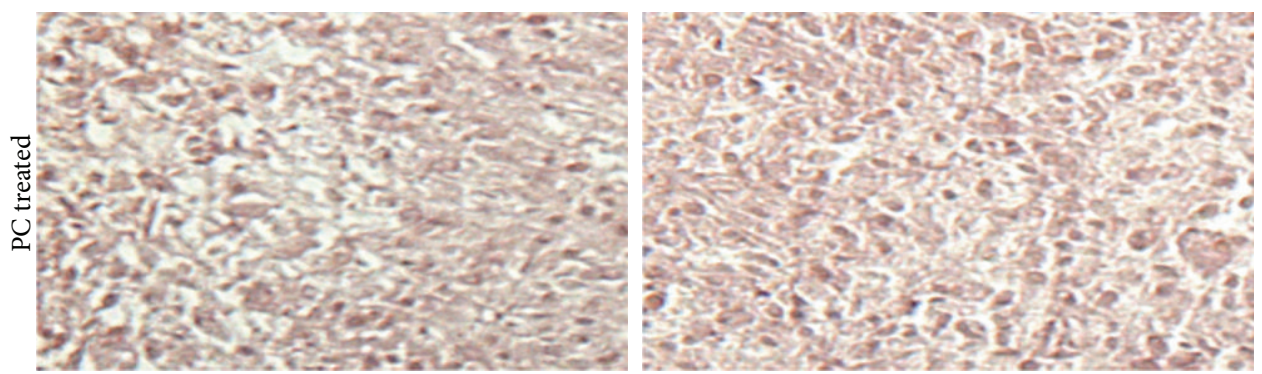

(b)

FIGURE 3: PC inhibited OA meniscal cells-mediated calcification in micromass culture. Micromasses of OA meniscal cells were stained with alizarin red. In the absence of PC, calcium deposits were detected ((a); magnification 10x). In the presence of $1 \mathrm{mM}$ PC, calcium deposits were abolished ((b); magnification 10x).

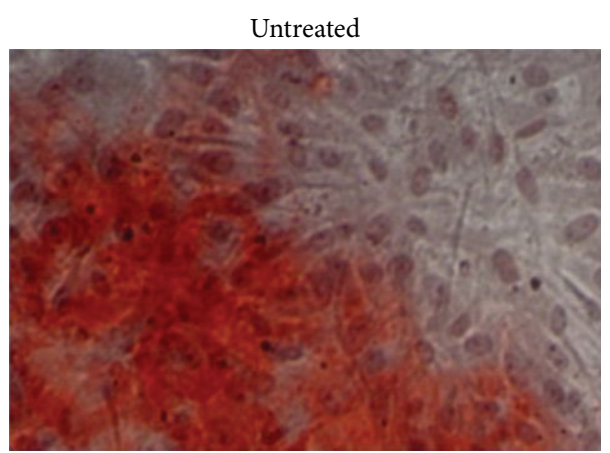

(a)

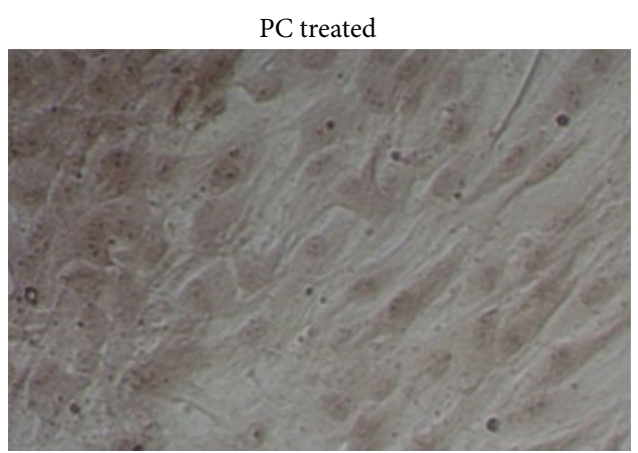

(b)

FIGURE 4: PC inhibited OA meniscal cells-mediated calcification in monolayer culture. In the absence of PC, calcium deposits were formed ((a); magnification 20x). In the presence of $1 \mathrm{mM}$ PC, no calcium deposits were formed ((b); magnification 20x).

Several previous observations provide support for this potential mechanism. For example, studies found that COL13 was increased in OA articular cartilage and that transgenic mice overexpressing COL13 had abnormally high bone mineral density $[35,36]$. The expression of ENPP1 and ANKH was elevated in OA meniscal cells, menisci, or articular cartilage $[4,34,37]$. SMAD1 induced terminal differentiation of chondrocytes and promoted calcification [38]. SATB2 stimulated osteogenic differentiation of adult stem cells [39]. These previous findings demonstrated that elevated expressions of COL13, ENPP1, ANKH, SMAD1, and SATB2 in OA cartilage or OA menisci were associated with terminal differentiation and biomineralization. The downregulatory effect of PC on these genes indicates that PC may reverse the processes of terminal differentiation and biomineralization.
Early studies demonstrated that MGP was a calcification inhibitor and that inhibition of IGFBP5 breakdown reduced articular cartilage loss in an experimental OA [40, 41]. In this study, we demonstrated that PC upregulated the expression of MGP (1.61-fold change) and IGFBP5 (1.78-fold change). This upregulatory effect of PC may lead to elevated production of MGP and IGFBP5.

FGF signaling pathway plays an important role in the regulation of osteogenesis and chondrogenesis. Studies found that FGF18 induced chondrocyte hypertrophy and mineralization [42, 43], while FGF9 inhibited terminal differentiation of calvaria-derived cells and mineralization [44, 45]. FGF7 was a potent inhibitor of phosphate transport [46]. In this study, we found that PC downregulated the expression of FGF18 (-1.73-fold change), while it upregulated the 
expression of FGF9 (2.38-fold change) and FGF7 (1.83-fold change). These regulatory effects indicate that PC may inhibit OA meniscal cell differentiation and pathological calcification in part by modulating the FGF signaling pathway. Consistently, studies have demonstrated that constitutive expression of thrombospondin 1 (THBS1), a protein involved in FGF signaling pathway, inhibited biomineralization and that THBS1 gene therapy suppressed the progression of arthritis in a rat model of OA $[47,48]$. Another study demonstrated that the absence of signaling through FGF receptor 3 (FGFR3) leads to premature cartilage degeneration and early arthritis [49]. These previous findings indicate a key role of FGF signaling pathway in the development of healthy articular cartilage. The specific upregulatory activity of PC on THBS1 (1.68-fold change) and FGF9 (a preferred ligand for FGFR3) indicates that PC may exert its disease-modifying activity on $\mathrm{OA}$ in part by modulating the FGF signaling pathway.

Severe loss of collagen occurs in OA menisci [50]. Disease-modifying drugs targeting meniscal degeneration for OA therapy should inhibit meniscal collagen loss. In this study, we demonstrated that PC stimulated the production of collagen by OA meniscal cells. This finding suggests that PC is not only potentially a disease-modifying drug for OA therapy but also potentially a meniscal protective agent.

Nonsteroidal anti-inflammatory drugs (NSAIDs) are widely used to treat arthritis. Traditional NSAIDs inhibit both PTGS1/Cox-1 and PTGS2/Cox-2, while new generation of NSAIDs selectively inhibits PTGS2/Cox-2. In this study, we demonstrated that PC downregulated the expression of PTGS1/Cox-1 (Table 1, -2.13-fold change). Further examination indicated that $\mathrm{PC}$ also downregulated the expression of PTGS2/Cox-2 (Table 1, -1.33-fold change). Moreover, PC downregulated the expression of PLA2G4A (-1.61-fold change), PLAUR (-1.94-fold change), and MMP9 (-1.91-fold change), all of which have been previously implicated in the pathogenesis of arthritis [51-53]. The findings presented in this study indicate that PC is potentially an anti-inflammation agent.

Interestingly, many genes classified in the inflammatory response were upregulated by $\mathrm{PC}$, including adenosine A1 receptor ADORA1 (2.48-fold change), CD24 (2.09-fold change), and BCL6 (1.98-fold change). It is worth noting that previous studies demonstrated that the activation of adenosine receptors reduced inflammation and joint destruction in a rat adjuvant-induced arthritis, CD24 repressed tissue damage-induced immune response, and that BCL6 inhibited the expression of chemokines and attenuated allergic airway inflammation [54-56]. These previous findings indicate that ADORA1, CD24, and BCL6 are potentially antiinflammation molecules. The upregulation of these genes by $\mathrm{PC}$ is consistent with the notion that PC is potentially an antiinflammation agent [57].

The genes downregulated by PC included NFKBIZ (-2.58-fold change), ADRB2 (-2.41-fold change), and CXCL6 (-2.19-fold change). Interestingly, studies demonstrated that NFKBIZ mediated IL-6 production, ADRB2 antagonists reduced the severity of arthritis, and that anti-CXCL16 antibody inhibited infiltration of inflammatory cells and arthritis [58-60]. These previous findings indicate that NFKBIZ,
ADRB2, and CXCL6 are proinflammation molecules. The downregulatory effect of PC on these genes is consistent with the notion that $\mathrm{PC}$ is potentially an anti-inflammation agent [57].

\section{Conclusions}

These specific biological activities of $\mathrm{PC}$ are intrinsic properties of PC and are not dependent on the presence of calcium crystals. PC is potentially an anti-inflammation and meniscal protective agent. PC is not only potentially a diseasemodifying drug for crystal-associated OA but also potentially a disease-modifying drug for arthritis associated with severe meniscal degeneration. The findings presented in this study provide further support for the development of PC, and/or its analogues, as disease-modifying drugs for OA therapy.

\section{Conflict of Interests}

The authors declare no conflict of interests.

\section{Acknowledgments}

This study is supported in part by an NC Biotech Center Grant, a Charlotte-Mecklenburg Education and Research Foundation Grant, and a Mecklenburg County Medical Society Smith Arthritis Fund Grant (to Yubo Sun). This study was performed at Carolinas Medical Center, Charlotte, NC, USA. The authors would like to thank Natalia Zinchenko for her help with histological examinations of micromasses.

\section{References}

[1] L. D. Bennett and J. C. Buckland-Wright, "Meniscal and articular cartilage changes in knee osteoarthritis: a cross-sectional double-contrast macroradiograpahic study," Rheumatology, vol. 41, no. 8, pp. 917-923, 2002.

[2] D. J. Hunter, Y. Q. Zhang, X. Tu et al., "Change in joint space width: hyaline articular cartilage loss or alteration in meniscus?" Arthritis and Rheumatism, vol. 54, no. 8, pp. 24882495, 2006.

[3] M. Englund, A. Guermazi, F. W. Roemer et al., "Meniscal tear in knees without surgery and the development of radiographic osteoarthritis among middle-aged and elderly persons: the multicenter osteoarthritis study," Arthritis and Rheumatism, vol. 60, no. 3, pp. 831-839, 2009.

[4] Y. Sun, D. R. Mauerhan, P. R. Honeycutt et al., "Analysis of meniscal degeneration and meniscal gene expression," $B M C$ Musculoskeletal Disorders, vol. 11, article 19, 2010.

[5] Y. Sun and D. R. Mauerhan, "Meniscal calcification, pathogenesis and implications," Current Opinion in Rheumatology, vol. 24, no. 2, pp. 152-157, 2012.

[6] M. Englund, A. Guermazi, and L. S. Lohmander, "The meniscus in knee osteoarthritis," Rheumatic Disease Clinics of North America, vol. 35, no. 3, pp. 579-590, 2009.

[7] Y. Sun, D. R. Mauerhan, P. R. Honeycutt et al., "Calcium deposition in osteoarthritic meniscus and meniscal cell culture," Arthritis Research and Therapy, vol. 12, no. 2, article R56, 2010.

[8] C. Pauli, S. P. Grogan, S. Patil et al., "Macroscopic and histopathologic analysis of human knee menisci in aging and 
osteoarthritis," Osteoarthritis and Cartilage, vol. 19, no. 9, pp. 1132-1141, 2011.

[9] G. M. McCarthy, P. G. Mitchell, and H. S. Cheung, "The mitogenic response to stimulation with basic calcium phosphate crystals is accompanied by induction and secretion of collagenase in human fibroblasts," Arthritis and Rheumatism, vol. 34, no. 8, pp. 1021-1030, 1991.

[10] Y. Sun, X. R. Zeng, L. Wenger, and H. S. Cheung, "Basic calcium phosphate crystals stimulate the endocytotic activity of cells-inhibition by anti-calcification agents," Biochemical and Biophysical Research Communications, vol. 312, no. 4, pp. 10531059, 2003.

[11] M. P. Morgan, L. C. Whelan, J. D. Sallis, C. J. McCarthy, D. J. Fitzgerald, and G. M. McCarthy, "Basic calcium phosphate crystal-induced prostaglandin E2 production in human fibroblasts: role of cyclooxygenase 1 , cyclooxygenase 2 , and interleukin-1 $\beta$," Arthritis and Rheumatism, vol. 50, no. 5, pp. 1642-1649, 2004.

[12] W. P. Tew, C. D. Malis, J. E. Howard, and A. L. Lehninger, "Phosphocitrate inhibits mitochondrial and cytosolic accumulation of calcium in kidney cells in vivo," Proceedings of the National Academy of Sciences of the United States of America, vol. 78, no. 9, pp. 5528-5532, 1981.

[13] L. Moro, N. Stagni, E. Luxich, J. D. Sallis, and B. De Bernard, "Evidence in vitro for an enzymatic synthesis of phosphocitrate," Biochemical and Biophysical Research Communications, vol. 170, no. 1, pp. 251-258, 1990.

[14] M. Romanello, M. Michalsky, N. Stagni, L. Moro, D. Favretto, and P. Traldi, "High-performance liquid chromatographic and mass spectrometric identification of phosphocitrate synthesized by human kidney homogenate," Journal of Chromatography, vol. 616, no. 2, pp. 167-173, 1993.

[15] G. Williams and J. D. Sallis, "Structure-activity relationship of inhibitors of hydroxyapatite formation," Biochemical Journal, vol. 184, no. 1, pp. 181-184, 1979.

[16] G. Williams and J. D. Sallis, "Structural factors influencing the ability of compounds to inhibit hydroxyapatite formation," Calcified Tissue International, vol. 34, no. 2, pp. 169-177, 1982.

[17] R. Shankar, S. Crowden, and J. D. Sallis, "Phosphocitrate and its analogue $\mathrm{N}$-sulpho-2-amino tricarballylate inhibit aortic calcification," Atherosclerosis, vol. 52, no. 2, pp. 191-198, 1984.

[18] D. Nair, R. P. Misra, J. D. Sallis, and H. S. Cheung, "Phosphocitrate inhibits a basic calcium phosphate and calcium pyrophosphate dihydrate crystal-induced mitogen-activated protein kinase cascade signal transduction pathway," Journal of Biological Chemistry, vol. 272, no. 30, pp. 18920-18925, 1997.

[19] H. S. Cheung, J. D. Sallis, and J. A. Struve, "Specific inhibition of basic calcium phosphate and calcium pyrophosphate crystalinduction of metalloproteinase synthesis by phosphocitrate," Biochimica et Biophysica Acta, vol. 1315, no. 2, pp. 105-111, 1996.

[20] Y. Sun, P. Reuben, L. Wenger, J. D. Sallis, K. D. Demadis, and H. S. Cheung, "Inhibition of calcium phosphate-DNA coprecipitates induced cell death by phosphocitrates," Frontiers in Bioscience, vol. 10, pp. 803-808, 2005.

[21] H. S. Cheung, J. D. Sallis, K. D. Demadis, and A. Wierzbicki, "Phosphocitrate blocks calcification-induced articular joint degeneration in a guinea pig model," Arthritis and Rheumatism, vol. 54, no. 8, pp. 2452-2461, 2006.

[22] M. Ding, C. C. Danielsen, and I. Hvid, "The effects of bone remodeling inhibition by alendronate on three-dimensional microarchitecture of subchondral bone tissues in guinea pig primary osteoarthrosis," Calcified Tissue International, vol. 82, no. 1, pp. 77-86, 2008.

[23] M. Walton, "The effects of long-term administration of ethane1-hydroxy-1, 1-diphosphonate on osteoarthrosis and heterotopic ossification in the mouse knee joint," Clinical Orthopaedics and Related Research, vol. 155, pp. 218-223, 1981.

[24] P. A. Turhanen, K. D. Demadis, S. Peräniemi, and J. J. Vepsäläinen, "A novel strategy for the preparation of naturally occurring phosphocitrate and its partially esterified derivatives," Journal of Organic Chemistry, vol. 72, no. 4, pp. 1468-1471, 2007.

[25] H. J. Mankin and L. Lippiello, "Biochemical and metabolic abnormalities in articular cartilage from osteo-arthritic human hips," Journal of Bone and Joint Surgery A, vol. 52, no. 3, pp. 424434, 1970.

[26] M. K. Lotz, S. Otsuki, S. P. Grogan, R. Sah, R. Terkeltaub, and D. D'Lima, "Cartilage cell clusters," Arthritis and Rheumatism, vol. 62, no. 8, pp. 2206-2218, 2010.

[27] D. Pfander, D. Körtje, G. Weseloh, and B. Swoboda, "Cell proliferation in osteoarthritic human cartilage," Zeitschrift fur Orthopadie und Ihre Grenzgebiete, vol. 139, no. 5, pp. 375-381, 2001.

[28] M. P. Hellio Le Graverand, P. Sciore, J. Eggerer et al., "Formation and phenotype of cell clusters in osteoarthritic meniscus," Arthritis \& Rheumatism, vol. 44, no. 8, pp. 1808-1818, 2001.

[29] S. Hashimoto, R. L. Ochs, S. Komiya, and M. Lotz, "Linkage of chondrocyte apoptosis and cartilage degradation in human osteoarthritis," Arthritis \& Rheumatism, vol. 41, no. 9, pp. 1632$1638,1998$.

[30] F. J. Blanco, R. Guitian, E. Vazquez-Martul, F. J. de Toro, and F. Galdo, "Osteoarthritis chondrocytes die by apoptosis. A possible pathway for osteoarthritis pathology," Arthritis \& Rheumatism, vol. 41, no. 2, pp. 284-289, 1998.

[31] K. Von der Mark, T. Kirsch, A. Nerlich et al., "Type X collagen synthesis in human osteoarthritic cartilage: indication of chondrocyte hypertrophy," Arthritis and Rheumatism, vol. 35, no. 7, pp. 806-811, 1992.

[32] O. Pullig, G. Weseloh, D. L. Ronneberger, S. M. Käkönen, and B. Swoboda, "Chondrocyte differentiation in human osteoarthritis: expression of osteocalcin in normal and osteoarthritic cartilage and bone," Calcified Tissue International, vol. 67, no. 3, pp. 230-240, 2000.

[33] X. Wang, P. A. Manner, A. Horner, L. Shum, R. S. Tuan, and G. H. Nuckolls, "Regulation of MMP-13 expression by RUNX2 and FGF2 in osteoarthritic cartilage," Osteoarthritis and Cartilage, vol. 12, no. 12, pp. 963-973, 2004.

[34] K. Johnson, S. Hashimoto, M. Lotz, K. Pritzker, J. Goding, and R. Terkeltaub, "Up-regulated expression of the phosphodiesterase nucleotide pyrophosphatase family member PC-1 is a marker and pathogenic factor for knee meniscal cartilage matrix calcification," Arthritis \& Rheumatism, vol. 44, no. 5, pp. 1071-1081, 2001.

[35] C. Karlsson, T. Dehne, A. Lindahl et al., "Genome-wide expression profiling reveals new candidate genes associated with osteoarthritis," Osteoarthritis and Cartilage, vol. 18, no. 4, pp. 581-592, 2010.

[36] R. Ylönen, T. Kyrönlahti, M. Sund et al., "Type XIII collagen strongly affects bone formation in transgenic mice," Journal of Bone and Mineral Research, vol. 20, no. 8, pp. 1381-1393, 2005.

[37] K. Ijiri, L. F. Zerbini, H. Peng et al., "Differential expression of GADD $45 \beta$ in normal and osteoarthritic cartilage: potential 
role in homeostasis of articular chondrocytes," Arthritis and Rheumatism, vol. 58, no. 7, pp. 2075-2087, 2008.

[38] C. A. Hellingman, E. N. B. Davidson, W. Koevoet et al., "Smad signaling determines chondrogenic differentiation of bone-marrow-derived mesenchymal stem cells: inhibition of Smad1/5/8P prevents terminal differentiation and calcification," Tissue Engineering A, vol. 17, no. 7-8, pp. 1157-1167, 2011.

[39] J. Zhang, Q. Tu, R. Grosschedl et al., "Roles of SATB2 in osteogenic differentiation and bone regeneration," Tissue Engineering A, vol. 17, no. 13-14, pp. 1767-1776, 2011.

[40] J. Oyoung, Y. Liao, Y. Xiao et al., "Matrix gla protein inhibits ectopic calcification by a direct interaction with hydroxyapatite crystals," Journal of the American Chemical Society, vol. 133, no. 45, pp. 18406-18412, 2011.

[41] D. R. Clemmons, W. H. Busby Jr., A. Garmong et al., "Inhibition of insulin-like growth factor binding protein 5 proteolysis in articular cartilage and joint fluid results in enhanced concentrations of insulin-like growth factor 1 and is associated with improved osteoarthritis," Arthritis and Rheumatism, vol. 46, no. 3, pp. 694-703, 2002.

[42] Z. Liu, K. J. Lavine, I. H. Hung, and D. M. Ornitz, "FGF18 is required for early chondrocyte proliferation, hypertrophy and vascular invasion of the growth plate," Developmental Biology, vol. 302, no. 1, pp. 80-91, 2007.

[43] A. A. Zalutskaya, M. K. Cox, and M. B. Demay, "Phosphate regulates embryonic endochondral bone development," Journal of Cellular Biochemistry, vol. 108, no. 3, pp. 668-674, 2009.

[44] N. B. Weksler, G. P. Lunstrum, E. S. Reid, and W. A. Horton, "Differential effects of fibroblast growth factor (FGF) 9 and FGF2 on proliferation, differentiation and terminal differentiation of chondrocytic cells in vitro," Biochemical Journal, vol. 342, part 3, pp. 677-682, 1999.

[45] A. Fakhry, C. Ratisoontorn, C. Vedhachalam et al., "Effects of FGF-2/-9 in calvarial bone cell cultures: differentiation stagedependent mitogenic effect, inverse regulation of BMP-2 and noggin, and enhancement of osteogenic potential," Bone, vol. 36, no. 2, pp. 254-266, 2005.

[46] T. O. Carpenter, B. K. Ellis, K. L. Insogna, W. M. Philbrick, J. Sterpka, and R. Shimkets, "Fibroblast growth factor 7: an inhibitor of phosphate transport derived from oncogenic osteomalacia-causing tumors," Journal of Clinical Endocrinology and Metabolism, vol. 90, no. 2, pp. 1012-1020, 2005.

[47] A. Ueno, Y. Miwa, K. Miyoshi et al., "Constitutive expression of thrombospondin 1 in MC3T3-E1 steoblastic cells inhibits mineralization," Journal of Cellular Physiology, vol. 209, no. 2, pp. 322-332, 2006.

[48] J. L. Hsieh, P. C. Shen, A. L. Shiau et al., "Intraarticular gene transfer of thrombospondin-1 suppresses the disease progression of experimental osteoarthritis," Journal of Orthopaedic Research, vol. 28, no. 10, pp. 1300-1306, 2010.

[49] G. Valverde-Franco, J. S. Binette, W. Li et al., "Defects in articular cartilage metabolism and early arthritis in fibroblast growth factor receptor 3 deficient mice," Human Molecular Genetics, vol. 15, no. 11, pp. 1783-1792, 2006.

[50] Y. Sun, D. R. Mauerhan, J. S. Kneisl et al., "Histological examination of collagen and proteoglycan changes in osteoarthritic menisci," Open Rheumatology Journal, vol. 6, pp. 24-32, 2012.

[51] L. Leistad, A. J. Feuerherm, A. Faxvaag, and B. Johansen, "Multiple phospholipase A2 enzymes participate in the inflammatory process in osteoarthritic cartilage," Scandinavian Journal of Rheumatology, vol. 40, no. 4, pp. 308-316, 2011.
[52] N. Tai, K. Kuwabara, M. Kobayashi et al., "Cytosolic phospholipase A2 alpha inhibitor, pyrroxyphene, displays anti-arthritic and anti-bone destructive action in a murine arthritis model," Inflammation Research, vol. 59, no. 1, pp. 53-62, 2010.

[53] S. C. Chu, S. F. Yang, K. H. Lue, Y. S. Hsieh, T. Y. Hsiao, and K. H. Lu, "Urokinase-type plasminogen activator, receptor, and inhibitor correlating with gelatinase-B (MMP-9) contribute to inflammation in gouty arthritis of the knee," Journal of Rheumatology, vol. 33, no. 2, pp. 311-317, 2006.

[54] D. L. Boyle, J. Moore, L. Yang, L. S. Sorkin, and G. S. Firestein, "Spinal adenosine receptor activation inhibits inflammation and joint destruction in rat adjuvant-induced arthritis," Arthritis and Rheumatism, vol. 46, no. 11, pp. 3076-3082, 2002.

[55] G. Y. Chen, J. Tang, P. Zheng, and Y. Liu, "CD24 and siglec-10 selectively repress tissue damage-induced immune responses," Science, vol. 323, no. 5922, pp. 1722-1725, 2009.

[56] T. Seto, M. Yoshitake, T. Ogasawara et al., "Bcl6 in pulmonary epithelium coordinately controls the expression of the CC-type chemokine genes and attenuates allergic airway inflammation," Clinical and Experimental Allergy, vol. 41, no. 11, pp. 1568-1578, 2011.

[57] Y. Sun, D. R. Mauerhan, A. M. Franklin, J. Norton, E. N. Hanley Jr., and H. E. Gruber, "Phosphocitrate is potentially a disease-modifying drug for noncrystal-associated osteoarthritis," BioMed Research International, vol. 2013, Article ID 326267, 11 pages, 2013.

[58] S. Seshadri, Y. Kannan, S. Mitra, J. Parker-Barnes, and M. D. Wewers, "MAIL regulates human monocyte IL-6 production," Journal of Immunology, vol. 183, no. 8, pp. 5358-5368, 2009.

[59] J. D. Levine, T. J. Coderre, C. Helms, and A. I. Basbaum, “ $\beta 2$ Adrenergic mechanisms in experimental arthritis," Proceedings of the National Academy of Sciences of the United States of America, vol. 85, no. 12, pp. 4553-4556, 1988.

[60] T. Nanki, T. Shimaoka, K. Hayashida, K. Taniguchi, S. Yonehara, and N. Miyasaka, "Pathogenic role of the CXCL16-CXCR6 pathway in rheumatoid arthritis," Arthritis and Rheumatism, vol. 52, no. 10, pp. 3004-3014, 2005. 


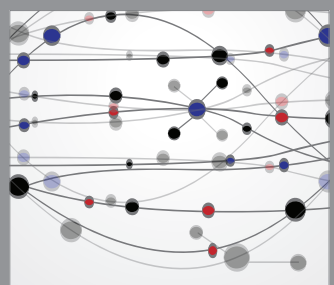

The Scientific World Journal
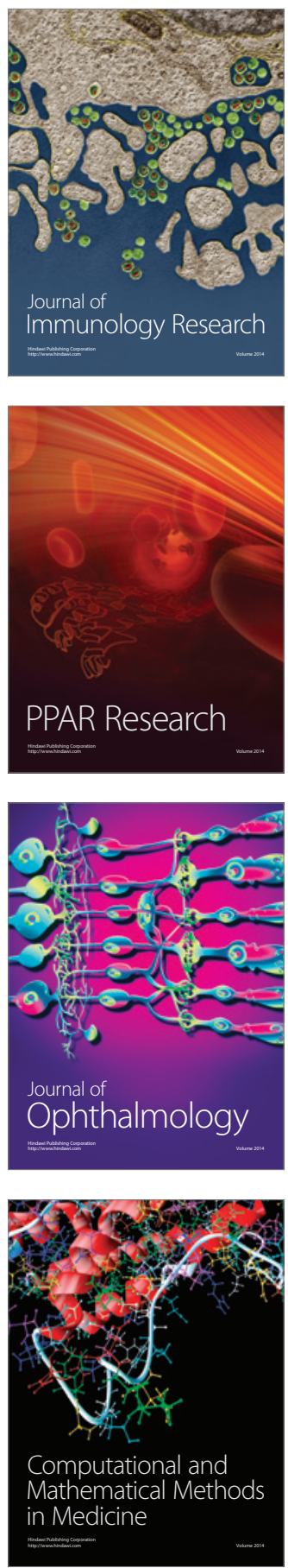

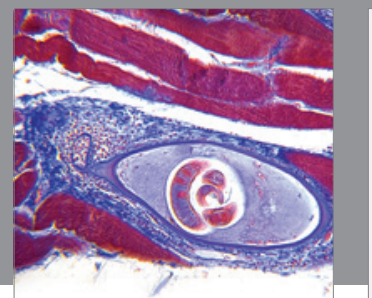

Gastroenterology

Research and Practice
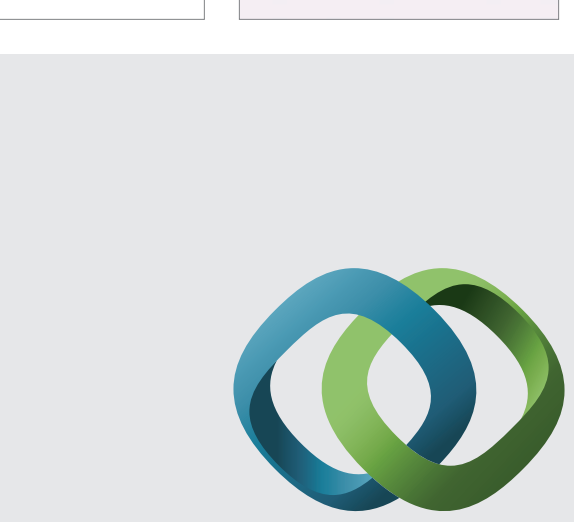

\section{Hindawi}

Submit your manuscripts at

http://www.hindawi.com
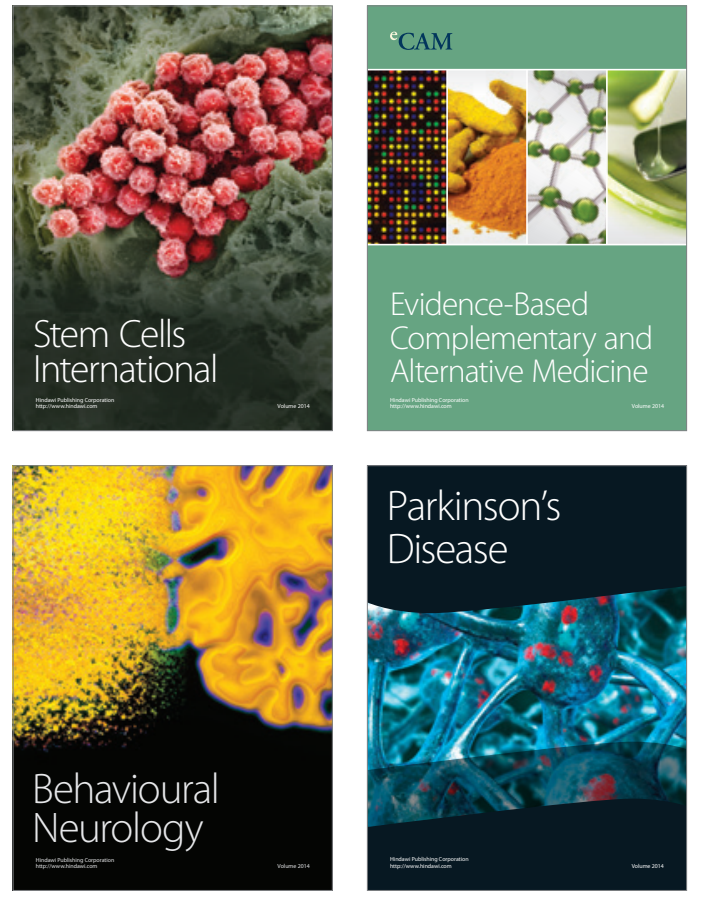
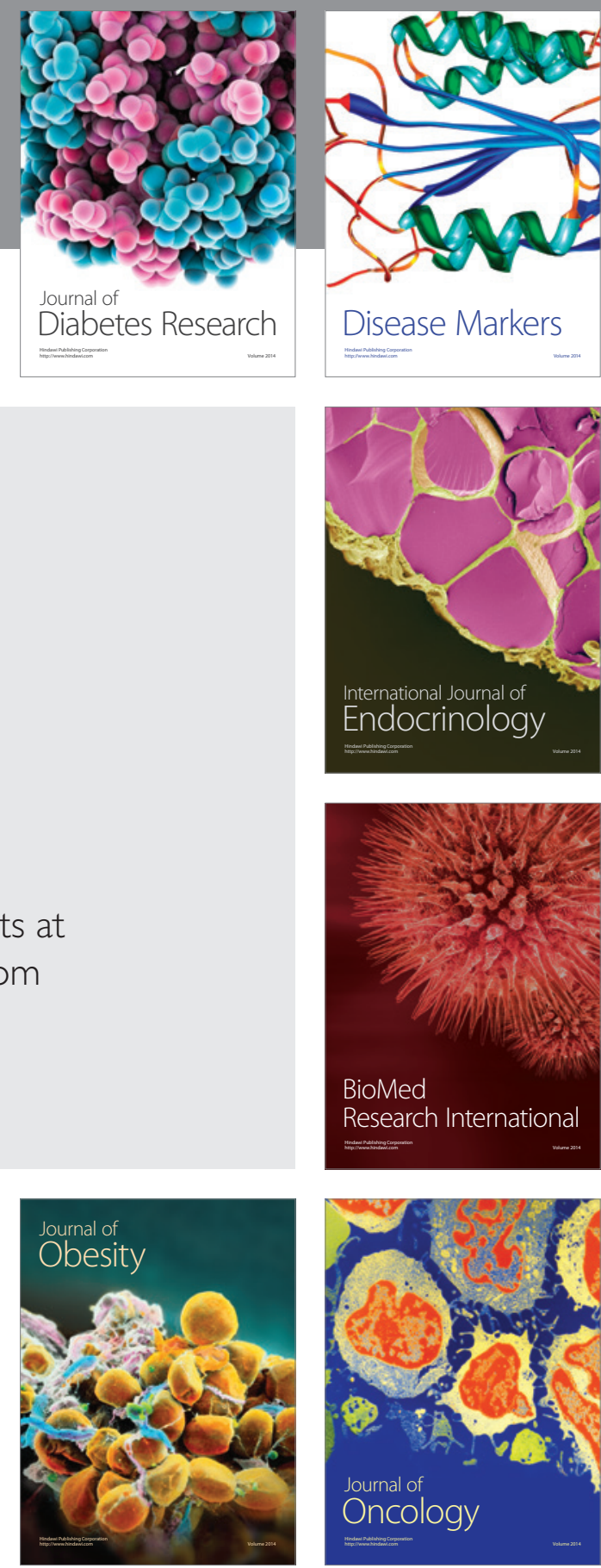

Disease Markers
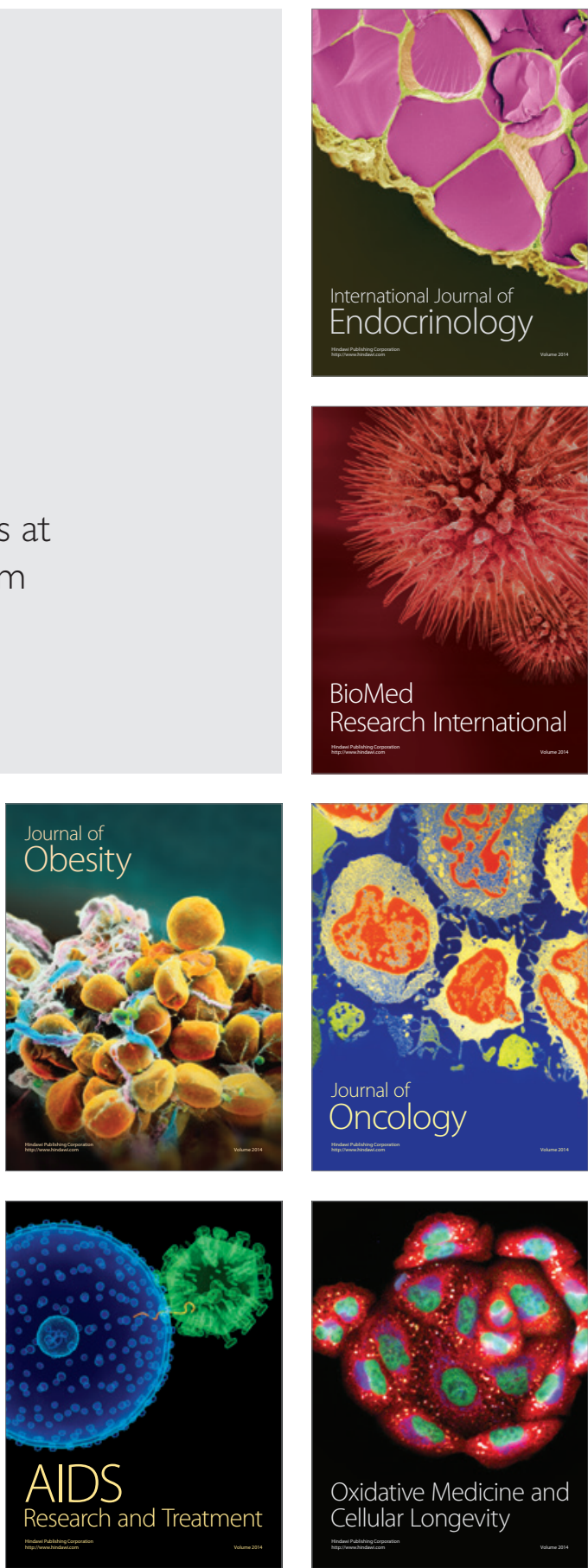